\title{
A Kunitz trypsin inhibitor from chickpea (Cicer arietinum L.) that exerts an antimicrobial effect on Fusarium oxysporum f.sp. ciceris
}

\author{
Meera Nair ${ }^{*}$, Sardul Singh Sandhu \\ Fungal Biotechnology and Invertebrate Pathology Laboratory, Department of Biological Sciences, Rani Durgavati University, \\ Jabalpur, India; ${ }^{*}$ Corresponding Author: meera.nair3@gmail.com
}

Received 31 August 2013; revised 29 September 2013; accepted 15 October 2013

Copyright (C) 2013 Meera Nair, Sardul Singh Sandhu. This is an open access article distributed under the Creative Commons Attribution License, which permits unrestricted use, distribution, and reproduction in any medium, provided the original work is properly cited.

\begin{abstract}
Fusarium oxysporum f.sp. ciceris (Foc) is one of the most important fungal pathogens of chickpea and is regarded as a constant threat in tropical and subtropical countries. In order to correlate Fusarium wilt resistance/susceptibility in Cicer arietinum to the presence or absence of trypsin inhibitor (TI) in the crude extract, trypsin inhibitory assay (TIA) and in vitro activity of $\mathrm{TI}$ against Foc were studied. In the present study, a $20 \mathrm{kDa}$ trypsin inhibitor was purified from Fusarium wilt resistant cultivar (viz. JG 2001-12) by ammonium sulfate precipitation, dialysis and chromatographies with Sephadex G-100 and Diethyl aminoethyl cellulose (DEAE-cellulose-52) ion-exchange column. Results of pathogenecity assay were found to be in correlation to the trypsin inhibitor assay where the Fusarium wilt resistant cultivar showed high trypsin inhibitory activity (99\%) in the presence of trypsin enzyme using both natural and synthetic substrates. Preliminary studies using crude extracts of JG 200112 showed a decrease in radial growth of Foc. A $45 \%-82 \%$ reduction in conidium germination at $20 \mu \mathrm{g} \cdot \mathrm{mL}^{-1}$ Cicer arietinum trypsin inhibitor (CaTI) concentration was observed, thereby, indicating the use of CaTI in suppression of pathogen and in its deployment through transgenic plants for the management of Fusarium wilt.
\end{abstract}

Keywords: Cicer arietinum; Fusarium Wilt; Kunitz; Proteinase Inhibitor; Trypsin Inhibitor

\section{INTRODUCTION}

Cicer arietinum (L.) is a worldwide leguminous crop, which ranks third in the world among pulse crops after peas and beans. Chickpea accounts a substantial proportion of human dietary nitrogen uptake and plays a crucial role in food security in developing countries [1]. Fusarium wilt caused by the Deuteromycetes fungal pathogen Fusarium oxysporum f.sp. ciceris (Foc) Schlechtend. Emend, Synder and Hansen, is a serious devastating disease of chickpea in India, Iran, Pakistan, Nepal, Burma, Spain, Tunisia and Mexico. It is a major pathogen, among 67 reported pathogens, to cause disease in Cicer arietinum (L.). Annual yield losses due to this disease estimate a $10 \%$ to $15 \%$ loss, but Fusarium wilt epidemics can cause a $100 \%$ loss under favorable conditions [2]. Persistence of the pathogen in soil and its capacity to survive there for years even in the absence of host [3] renders its control difficult [4]. Soil applications of fungicides are costly and lead to indiscriminate killing of beneficial soil microflora, therefore alternative biocontrol agents or other eco-friendly control strategies are necessary [4].

One of the eco-friendly control measures opted to provide resistance against fungal pathogens is using a proteinase inhibitor (PI) proteins produced in plant tissues, which, act as a defensive mechanism against microorganisms [5]. Plant PIs rely on inhibition of proteases secreted by microorganisms, causing a reduction in the availability of amino acids necessary for their growth and development [6].

C. arietinum (L.) seeds are rich in serine proteinase inhibitors (PIs) which show strong inhibitory activity against trypsin, chymotrypsin or other proteolytic enzymes [7]. In our earlier study, trypsin inhibitor showed antimetabolitic activity against Helicoverpa armigera [8]. Accordingly, an attempt has been made to analyze antifungal activity of trypsin inhibitor towards the growth of Foc and its influence on hyphal growth. To the best of 
our knowledge, this is the first study focusing on the use of C. arietinum (L.) trypsin inhibitor (CaTI) on Fusarium wilt control.

\section{MATERIALS AND METHODS}

\subsection{Fungal Cultures}

Standard isolates of Foc (MTCC \# 2087) was procured from Microbial Type Culture Collection and Gene Bank (MTCC), IMTECH (Institute of Microbial Technology), Chandigarh where they were already characterized and classified for their race specificity using conventional method of race identification. The cultures were maintained on Potato Dextrose Agar (PDA) slants with timely sub-culturing and infection to a susceptible cultivar, JG 62.

\subsection{Plant Material}

Cicer arietinum (L.) cultivar seeds viz. JG 2001-12, JG 16 and JG 62 used in this study were obtained from Department of Genetics and Plant Breeding, Jawaharlal Nehru Krishi Vishwavidhyalaya (J.N.K.V.V.), Jabalpur, India. Each plant were grown from single seed, planted in a rectangular trough and maintained under green house conditions. Cultivar JG 62 (pedigree-selection from germplasm), is susceptible to Fusarium wilt.

\subsection{Pathogenecity Assay}

Seeds of $C$. arietinum (L.) cultivar viz. JG 62, JG 2001-12 and JG 16 were pre-germinated and grown in 20 $\times 10 \times 2.25 \mathrm{~cm}$ trays filled with peat soil. Freshly prepared spore suspension $\left(1 \times 10^{6}\right.$ spores $\left.\cdot \mathrm{mL}^{-1}\right)$ of Foc \# 2087 was added individually to the sterile trays containing 7 day old chickpea plants. Seedlings grown in trays with no pathogen (un-inoculated plants) served as control. The pathogenecity assays were conducted in triplicates. Seedlings showing typical disease symptoms such as wilt, xylem discoloration and stunting were recorded for 21 days. Final disease severity data was recorded on $8^{\text {th }}$ week after inoculation. Pathogen was re-isolated from representative diseased plants so to prove Koch's postulates.

\subsection{Preliminary Proteinase (Trypsin) Inhibitor Assay}

Trypsin inhibitor activity (TIA) of crude extract was determined using both natural (casein) and synthetic oligopeptides substrate (BA $p$ NA) by pre-incubating $0.25 \mu \mathrm{g}$ trypsin $\left(10 \mathrm{mg} \cdot \mathrm{mL}^{-1}\right.$ of bovine trypsin in $\left.1 \mathrm{mM} \mathrm{HCl}\right)$ and $50 \mu \mathrm{l}$ of crude extract (12.5 $\mathrm{mg}$ protein) for $15 \mathrm{~min}$ in a water bath (D'sco, India) at $37^{\circ} \mathrm{C}$. Natural or synthetic oligopeptide substrate was then added and the reaction was carried out for $30 \mathrm{~min}$ at $37^{\circ} \mathrm{C}$. For caseinolytic as- say, reaction was stopped by adding $50 \mu \mathrm{l}$ of $50 \%(\mathrm{w} / \mathrm{v})$ TCA which was allowed to stand for $15 \mathrm{~min}$ at $4^{\circ} \mathrm{C}$. TCA-soluble material was collected by centrifuging the reaction mixture at $2000 \times \mathrm{g}$ for $20 \mathrm{~min}$. In $\mathrm{BA} p \mathrm{NA}$, the reaction was terminated by adding $0.5 \mathrm{~mL}$ of $10 \%$ acetic acid and absorbance at $410 \mathrm{~nm}$ was determined. The percentage at which casein was digested by trypsin was calculated by measuring the absorption of trichloroacetic acid (TCA) filtrate at $280 \mathrm{~nm}$ by using the tyrosine standard curve. Similarly, $p$ NA ( $p$-nitroaniline) was used as a standard for BA $p$ NA. Trypsin inhibition (\%) was calculated from the difference between untreated (without crude extract) and treated (with crude extract) samples divided by untreated sample reading, multiplied by 100 [9].

\subsection{Extraction of Chickpea PIs}

The seed extract of resistant cultivar viz. JG 2001-12 was prepared as per the method described by Nair et al. [8]. Soluble proteins were extracted from milled, defatted and depigmented seeds of chickpea in $10 \mathrm{mM}$ phosphate buffer, $\mathrm{pH} 7.2$ with constant stirring at $4^{\circ} \mathrm{C}$ for $4 \mathrm{~h}$. Inhibitor proteins were fractionated with ammonium sulphate $(40 \%-60 \%$ saturation), recovered by centrifugation at $12000 \times \mathrm{g}$ for $30 \mathrm{~min}$ at $4^{\circ} \mathrm{C}$ and later dissolved in a minimal amount of deionized water. The protein was concentrated against $50 \mathrm{mM}$ Tris/ $\mathrm{HCl}$ buffer, $\mathrm{pH} 7.5$ using dialysis membrane (Sigma Aldrich USA, $12 \mathrm{kDa}$ cut off) and loaded on a Sephadex G-100 $(50 \mathrm{~cm} \times 1 \mathrm{~cm})$ equilibrated with chilled $10 \mathrm{mM}$ Tris/ $\mathrm{HCl}$ buffer $(\mathrm{pH} 7.5)$ and eluted with the same buffer. Active fraction showing trypsin inhibitor activity was pooled and concentrated via acetone precipitation. Acetone treated aliquots $(500 \mu \mathrm{l})$ was loaded and left undisturbed for $30 \mathrm{~min}$. The inhibitor was eluted using 0 to $2 \mathrm{M} \mathrm{NaCl}$ linear gradients at $4^{\circ} \mathrm{C}$. Total protein was assayed by Lowry et al. [10] using bovine serum albumin as a standard.

\subsection{Polyacrylamide Gel Electrophoresis Analysis}

Sodium dodecyl sulfate-polyacrylamide gel electrophoresis (SDS-PAGE) was performed according to the protocol of Laemmli [11] with $4 \%$ stacking gel and $12 \%$ separating gel using a vertical gel electrophoresis system (GeNei, Bangalore, India), where anion exchange fraction along with standard protein molecular weight marker (Bangalore Genei, India) was loaded to the wells. The gel was run at a constant voltage of $50 \mathrm{~V}$ at $4^{\circ} \mathrm{C}$ in electrophoresis buffer $(25 \mathrm{mM}$ Tris/ $\mathrm{HCl} \mathrm{pH} 8.8,192 \mathrm{mM}$ glycine and $0.1 \%(\mathrm{w} / \mathrm{v}) \mathrm{SDS})$ following which, the entire gel was washed with distilled water and stained with Commassie brilliant blue stain $\left(\right.$ Calbiochem ${ }^{\circledR}$ ) for $30 \mathrm{~min}$ with constant shaking. The gel was later destained with 
methanol:glacial acetic acid:distilled water (v/v) (3:2:15) for one hour giving three changes of destain.

\subsection{In-Gel Assay of Proteinase Inhibitor}

Gelatin zymography were performed according to Le and Katunuma [12] with resolving $10 \%$ acrylamide solution containing $0.1 \%$ gelatin. Ion exchange chromatography fraction equivalent to $40 \mu \mathrm{g}$ protein were mixed with equal volume of sample buffer containing $25 \mathrm{mM}$ Tris/HCl (pH 6.8), 20\% glycerol, 4\% SDS and $0.02 \%$ bromophenol blue was loaded along with $80 \mu \mathrm{g}$ of soybean trypsin inhibitor $\left(\right.$ Calbiochem $\AA ; 10 \mathrm{mg} \cdot \mathrm{mL}^{-1}$ stock solution in Tris/ $\mathrm{HCl} \mathrm{pH} 8.2$ ) which was used as a marker. Electrophoresis was performed at a constant voltage of $50 \mathrm{~V}$ at $4^{\circ} \mathrm{C}$ in electrophoresis buffer $(25 \mathrm{mM}$ Tris $/ \mathrm{HCl}$, $\mathrm{pH} 8.8,192 \mathrm{mM}$ glycine and 0.1\% SDS). The gel was washed for $30 \mathrm{~min}$ at room temperature with $0.1 \mathrm{M}$ Tris$\mathrm{HCl}$ at $\mathrm{pH} 7.2$ containing $2.5 \%$ Triton X-100, followed by distilled water for $20 \mathrm{~min}$. Subsequent incubation at $37^{\circ} \mathrm{C}$ for $3 \mathrm{~h}$ with reaction buffer containing $10 \mathrm{mg} \cdot \mathrm{mL}^{-1}$ trypsin solution (10 $\mathrm{mg}$ trypsin in $0.1 \mathrm{M}$ Tris $/ \mathrm{HCl}, \mathrm{pH} 7.5)$ and $0.02 \% \mathrm{NaN}_{3}$ followed by Coomassie Brilliant Blue R250 (CBB) staining for $1 \mathrm{~h}$ and destaining produced blue bands against a clear background.

\subsection{Determination of Proteinase (Trypsin) Inhibitor Activity at Different Stages of Purification Steps}

The proteinase inhibitor activity on natural and synthetic chromo(non-chromo)genic substrates was determined in a reaction mixture containing $50 \mathrm{mM}$ Tris/HCl buffer ( $\mathrm{pH}$ 7.5), $0.25 \mu \mathrm{g}$ trypsin (EC 3.4.21.4) (10 $\mathrm{mg} \cdot \mathrm{mL}^{-1}$ of bovine trypsin in $1 \mathrm{mM} \mathrm{HCl}$ ), different concentration of all three ammonium sulphate cut off (100 $\mu \mathrm{g})$, gel filtrate fraction $(100 \mu \mathrm{g})$ and ion exchange fractions. The anion exchange fractions $(43 \mu \mathrm{g}, 86 \mu \mathrm{g}, 430$ $\mu \mathrm{g}$ protein) with $100 \mu \mathrm{l}$ casein, $40 \mu \mathrm{l}$ BApNA (10 $\mathrm{mg} \cdot \mathrm{mL}^{-1}$ in dimethyl sulfoxide); $0.23 \mathrm{mM}$ BAEE in 67 $\mathrm{mM}$ potassium phosphate buffer ( $\mathrm{pH} 7.5), 12.5 \%$ azocasein (w/v) in $50 \mathrm{mM}$ Tris, $5 \mathrm{mM} \mathrm{CaCl} 2$ (pH 8.0). Controls with a trypsin enzyme $\left(100^{\circ} \mathrm{C}, 5 \mathrm{~min}\right)$ were run in parallel. The amount of $p$-nitroaniline $(p \mathrm{NA})$ released was determined by measuring the change in absorbance at $410 \mathrm{~nm}$ using $p$ NA calibration curve. Proteinase inhibitor (TI) activity was also determined using a nonchromogenic substrate N-benzoyl-L-arg ethyl ester (BAEE) according to Schwert and Takenaka [13].

In azocasein, the reaction was terminated by adding $200 \mu \mathrm{l}$ of ice-cold $5 \%$ TCA to $500 \mu \mathrm{l}$ of reaction mixture. The reaction mixture was then placed at room temperature for $10 \mathrm{~min}$ and centrifuged at $3,000 \times \mathrm{g}$ for $10 \mathrm{~min}$, the supernatant $(500 \mu \mathrm{l})$ was later aspirated and $1500 \mu \mathrm{l}$ of $0.5 \mathrm{M} \mathrm{NaOH}$ was added. The absorbance was recorded at $\mathrm{A}_{428}$ [14].

\subsection{Screening of Fungitoxic Activity}

The in vitro fungitoxic activity of crude extract of fusarium wilt resistant cultivar (viz. JG 2001-12) and fusarium wilt susceptible cultivar (viz. JG 16) was performed by mycelial disc method as described by Tremacoldi and Pascholati [15]. The mycelial disc was placed onto PDA medium, previously flooded with filtered $(0.2$ $\mu \mathrm{m}$, Millipore) crude extracts in $25 \mu \mathrm{l}, 500 \mu \mathrm{l}, 1000 \mu \mathrm{l}$ and $2000 \mu 1$ volumes. The experiment was performed in triplicate for each concentrations and controls (with no crude extract added) under strict aseptic conditions. The fungitoxic activity of each concentration was expressed in terms of the mean of colony diameter in $\mathrm{cm}$ (mean value \pm standard deviation) produced by respective extract at the end of the incubation period (7 d). Gel filtration fraction (Fraction A) was also tested against mycelia growth of Foc isolates at 10, 100 and $200 \mu \mathrm{g}$ of protein (as described above).

\subsection{Effect of Anion Exchange Fractions on the Hyphal and Conidial Growth of Fusarium oxysporum f.sp. ciceris}

The effect of purified CaTI protein (anion exchange fractions) on hyphal growth and conidial germination was assayed. Conidial suspension was prepared by flooding the cultures with sterile distilled water containing $0.05 \%(\mathrm{v} / \mathrm{v})$ Tween- 80 which was later filtered through four layers of sterilized cheesecloth to remove adhering mycelia. The spore concentration was adjusted to $10^{5}$ conidia per $\mathrm{mL}$ with the aid of Neubauer hemocytometer. Conidia were allowed to germinate and grown in the presence of CaTI at $0,5,10,15,20 \mu \mathrm{g} \cdot \mathrm{mL}^{-1}$ concentrations in 6-well plate at $25^{\circ} \mathrm{C}$ in darkness with a positive control and negative control plates containing heat inactivated CaTI and phosphate buffer. For each treatment, hyphal length was measured from 40 randomly selected hyphae and the mean hyphal length was used for comparison using a light microscope equipped with an ocular micrometer after $12 \mathrm{~h}$ and $24 \mathrm{~h}$ of incubation. As Foc is multicelled therefore; a conidium was considered germinated, if hyphae were visible for at least one of the cells. Each treatment contained three replicates and the experiment was repeated twice.

\subsection{Statistical Analysis}

The results were subjected to analysis of variance (ANOVA) and the significance of differences among means was determined by using t-test using the MS Excel program where $p$ values $<0.05$ were considered significant. All experiments were performed in triplicate unless stated otherwise. Comparisons were made for all 
parameters within the amount of inhibitor used as well as the hours of incubation during antimicrobial activity on Foc.

\section{RESULTS AND DISCUSSION}

\subsection{Pathogenecity Assays}

Chickpea plants viz. JG 62, JG 2001-12 and JG 16 were inoculated with fungal spores of Foc individually where un-inoculated plants served as control. Upon infection, JG 62 and JG 16 showed wilting symptoms by 10 days after inoculation (dai), while no wilting was observed in JG 2001-12 cultivar even by the $8^{\text {th }}$ week. Figure 1 shows the chickpea cultivars, where JG 16 exhibit wilting symptoms whereas JG 2001-12, display no wilting symptoms.

\subsection{Preliminary Proteinase (Trypsin) Inhibitor Activity}

The inhibitory activity of the crude extract (viz., JG 2001-12 and JG 16) against bovine trypsin was determined using natural and synthetic substrate viz. casein, BA $p$ NA respectively.

Caseinolytic activity: Crude extract of JG 2001-12 and JG 16 was used to determine the proteinase inhibitory activity where the specific activity of trypsin was found to be $227 \pm 0.5 \mathrm{nmol} \cdot \mathrm{tyr} \cdot \mathrm{min}^{-1} \cdot \mathrm{mg}^{-1}$ protein in absence of crude extract (trypsin inhibitor). The crude extract of Fusarium wilt resistant cultivar (viz. JG 200112) displayed a $99 \%$ trypsin inhibition with $0.7 \pm 0.4$ nmol $\cdot$ tyr $\cdot \mathrm{min}^{-1} \cdot \mathrm{mg}^{-1}$ protein. The caseinolytic activity of Fusarium wilt susceptible cultivar (viz. JG 16) showed a $12 \%$ inhibition with $200 \pm 0.5 \mathrm{nmol} \cdot \mathrm{tyr} \cdot \mathrm{min}^{-1} \cdot \mathrm{mg}^{-1}$ protein TIA (Table 1).

BApNA: Trypsin activity was rapidly inhibited (99.4\% inhibition) by the crude extract of $C$. arietinum fusarium wilt resistant cultivar (viz. JG 2001-12), indicating the presence of trypsin inhibitor with $1.0 \pm 0.3$ $\mu \mathrm{mol} p \mathrm{NA} \mathrm{min}^{-1} \mathrm{mg}^{-1}$ protein TIA against bovine trypsin (Table 1).

\subsection{Purification of Cicer Arietinum Trypsin Inhibitor (CaTI)}

The trypsin inhibitor from JG 2001-12 seed crude extract was identified by trypsin inhibitory activity (TIA) assays using trypsin as the enzyme at preliminary identification and purification steps. The purification results are presented in Figure $\mathbf{2}$ and Table 2. The proteinase inhibitor activity was revealed in $40 \%-60 \%$ ammonium sulphate cut off (Figure 3). Chickpea proteinase (trypsin) inhibitor was isolated by dialysis, desalting in Sephadex G-100 and purified using DEAE-cellulose column eluted with $0.1 \mathrm{M} \mathrm{NaCl}$. Upon size-exclusion chromatography
Table 1. Trypsin Inhibitory activity (TIA) of crude extracts of fusarium wilt resistant (JG 2001-12) and susceptible (JG 16) cultivars.

\begin{tabular}{cccccc}
\hline & & \multicolumn{2}{c}{ Casein } & \multicolumn{2}{c}{ BApNA } \\
\cline { 3 - 6 } & & TIA $^{*}$ & TI $^{\#}$ & TIA $^{*}$ & TI $^{*}$ \\
\hline \multirow{4}{*}{ Control } & $227.6 \pm 0.5$ & 0 & $172.01 \pm 0.5$ & 0 \\
& & \multicolumn{4}{c}{ Crude extract of cultivar } \\
1) & JG 16 & $200^{\mathrm{b}} \pm 0.5$ & 12 & $145.2^{\mathrm{a}} \pm 0.3$ & 15.5 \\
2) & JG 2001-12 & $0.7^{\mathrm{a}} \pm 0.4$ & 99 & $1.0^{\mathrm{b}} \pm 0.3$ & 99.4 \\
\hline
\end{tabular}

a,b Means with different superscripts in a column differs significantly $(p<$ 0.05). ${ }^{*}$ TIA $=$ nmol tyr $\min ^{-1} \mathrm{mg}^{-1}$ protein; ${ }^{* *}$ TIA $=\mu$ mol $p$ NA $\min ^{-1} \mathrm{mg}^{-1}$ protein; $\mathrm{TI}^{\#}=$ Trypsin Inhibition (\%).

Table 2. Purification performance of Trypsin Inhibitor from JG 2001-12 cultivar.

\begin{tabular}{|c|c|c|c|c|c|}
\hline Sample & $\begin{array}{c}\text { Total } \\
\text { protein } \\
\text { (mg) }\end{array}$ & $\begin{array}{c}\text { Specific } \\
\text { Activity } \\
(\mu \mathrm{M} \text { pNA } \\
\left.\text { min }^{-1} \mathrm{mg}^{-1}\right)\end{array}$ & TIA* & $\begin{array}{l}\text { Yield } \\
(\%)\end{array}$ & $\begin{array}{c}\text { Purification } \\
\text { Fold }\end{array}$ \\
\hline Crude Extract & 258 & 2.32 & 44.5 & 100 & 1 \\
\hline Sephadex G-100 & 9 & 72.54 & 86.7 & 25 & 57.1 \\
\hline $\begin{array}{c}\text { DEAE-cellulose-52 } \\
\text { column }\end{array}$ & 0.1 & 140 & 94.4 & 10 & 65.4 \\
\hline
\end{tabular}

${ }^{*}$ TIA $=$ Trypsin Inhibitory activity.

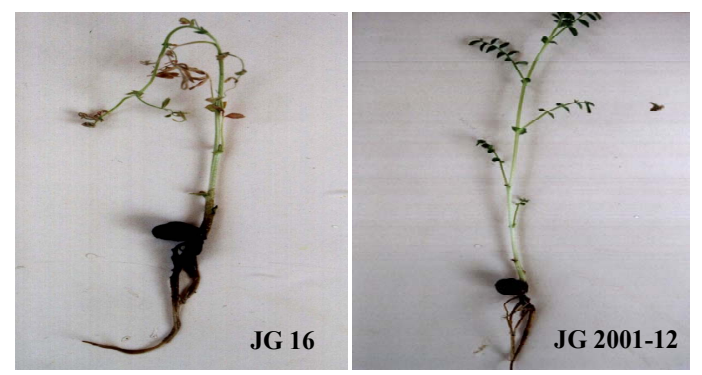

Figure 1. Fusarium wilt susceptible cultivar (JG 16) and resistant (JG 2001-12) showing wilting and chlorosis.

on Sephadex G-100 column, two protein peaks were obtained where proteinase inhibitor was detected in the first peak (Figure 2(a)) which consisted of three fractions (fraction 9, 10, 11 called as Fraction A). Fraction A showed maximum trypsin inhibitory activity against trypsin enzyme (Figures 4(a), (b)). Further, the trypsin inhibitor was retained by anion exchange columnDEAE-cellulose column and eluted in fractions of $0.1 \mathrm{M}$ $\mathrm{NaCl}$ (Figure 2(b)). Taken together, approximately 10\% recovery and 65.4 fold increase in specific activity resulted (Table 2). Fractions of size exclusion chromatography, anion exchange chromatography were employed on SDS-PAGE and reverse zymography (using gelatin as substrate) to verify the purity of trypsin inhibitor and 


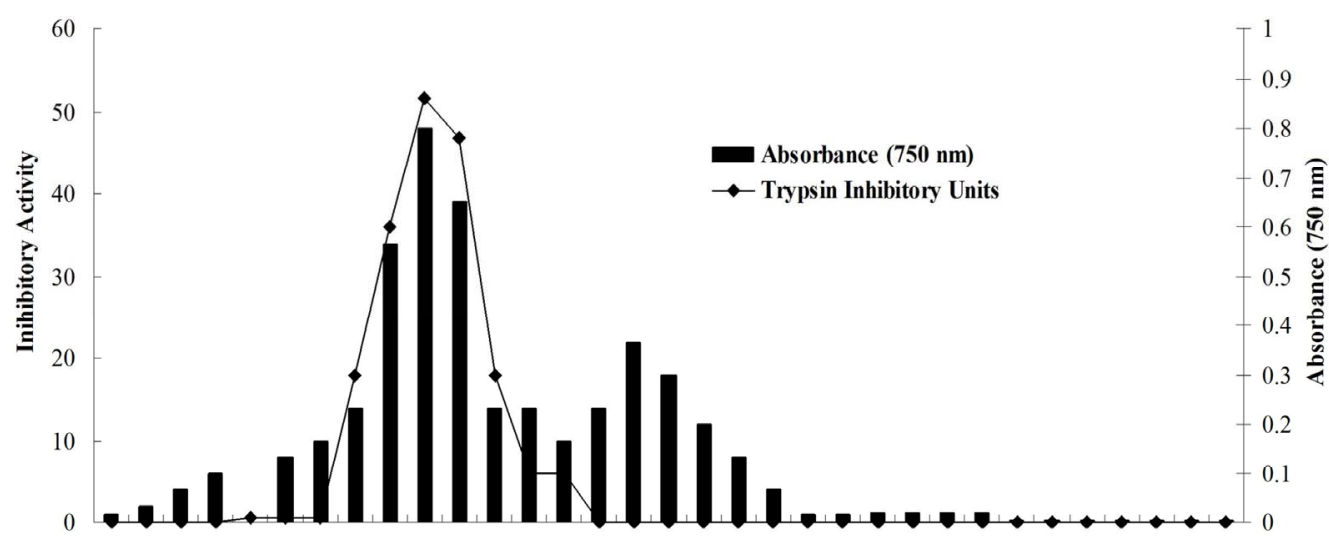

$1 \quad 2 \quad 3 \quad 4 \quad 5 \quad 6 \quad 7 \quad 8 \quad 91011 \quad 12131415161718192021222324252627282930313233$

Fractions

(a)

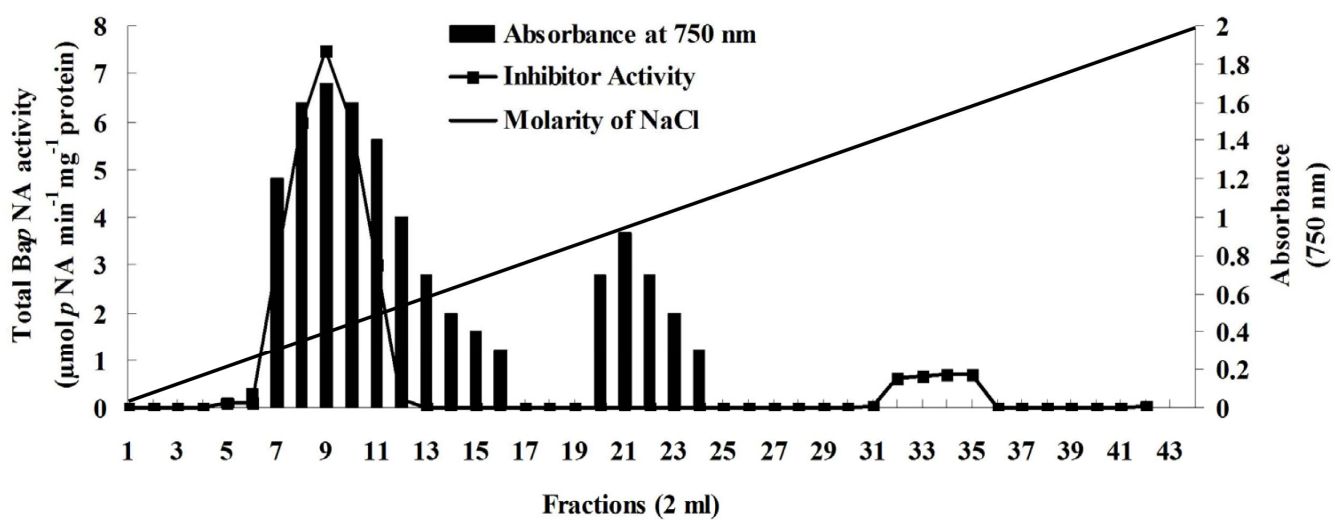

(b)

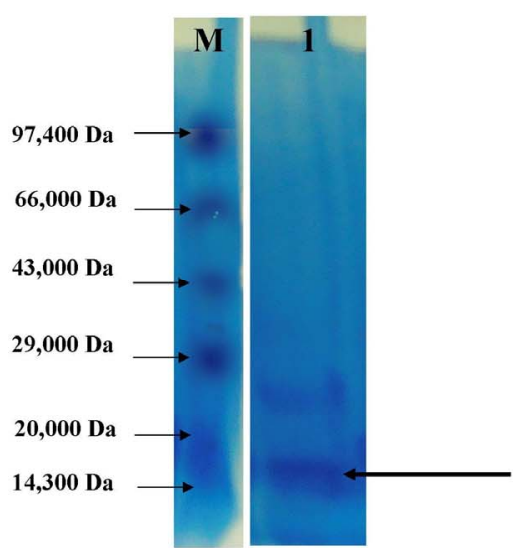

(c)

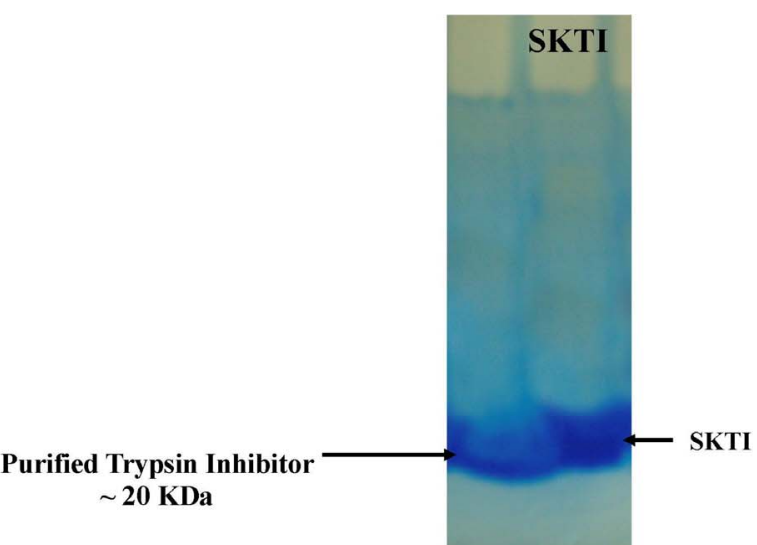

(d)

Figure 2. Purification of Trypsin inhibitor from JG 2001-12 seeds. (a) Separation using Sephadex G-100 column chromatography of trypsin inhibitor from seeds of Fusarium wilt resistant Cicer arietinum L. cultivar viz., JG 2001-12. (b) Purification of higher trypsin inhibitory region (fraction 9, 10, 11) identified after Sephadex G-100 chromatography using DEAE-cellulose ion exchange chromatography column. Line across the chromatography represents the linear $0-1 \mathrm{M} \mathrm{NaCl}$ gradient employed to elute adsorbed proteins. (c) SDS-PAGE gel of trypsin inhibitor purified using ion exchange chromatography with standard molecular weight marker (M). (d) In gel assay detection of trypsin inhibitory activity. Standard soybean kunitz trypsin inhibitor (SKTI) and Purified trypsin inhibitor from JG 2001-12 seeds.

estimate its molecular mass. Trypsin inhibitor was resolved by SDS-PAGE and in-gel digestion of gelatin in zymograms where both gels showed one band corresponding to $\mathrm{M}_{\mathrm{r}} \sim 20 \mathrm{kDa}$ (Figures 2(c) and (d)). 


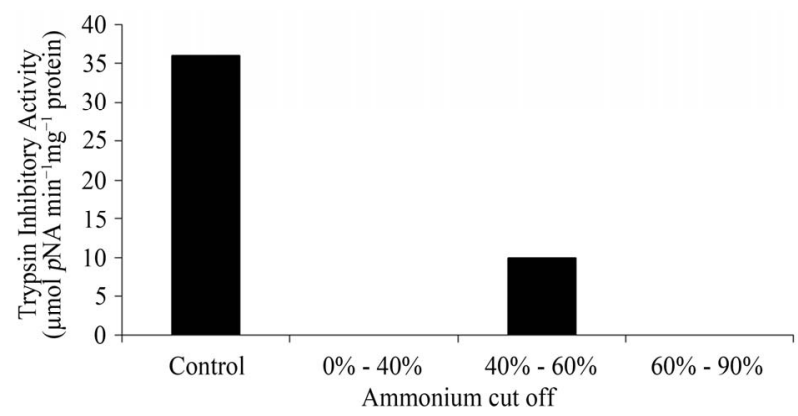

Figure 3. Trypsin Inhibitory Activity (TIA) in different ammonium sulphate cut offs of protein homogenate of JG 2001-12 cultivar in comparison to control (with no crude extract) using BA $p$ NA substrate.
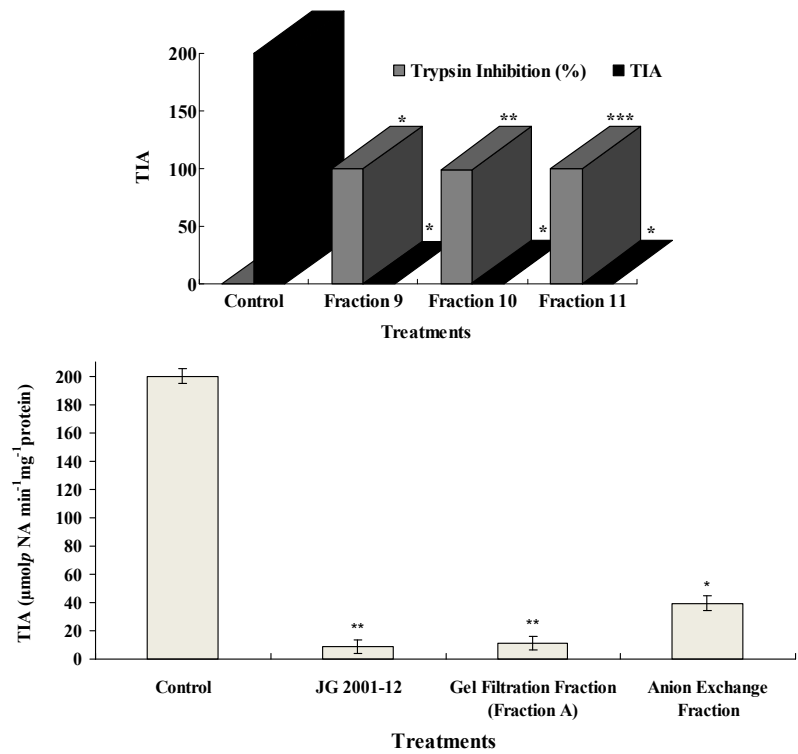

Figure 4. Trypsin Inhibitory Activity (TIA) Assay.

\subsection{Trypsin Inhibitor Activity Assay}

Trypsin inhibitor activity assay (TIA) of purified trypsin inhibitor at different purification steps using synthetic substrates (BApNA, azocasein, BAEE) were carried where the reliability of the reaction conditions was determined in triplicate sets. The TIA using BApNA substrate, at different concentration of CaTI protein $[(5 \mu \mathrm{L})$ $(43 \mu \mathrm{g}), 10(86 \mu \mathrm{g}), 15 \mu \mathrm{L}(430 \mu \mathrm{g})]$ showed a progressive reduction in trypsin activity, with increase in concentration of CaTI protein. The inhibitory activity was increased from $86.2 \%, 97.2 \%$ to $98.61 \%$ with protein concentration (Figure 5). Similarly, in azocasein and BAEE substrate, absorbance at $428 \mathrm{~nm}$ and $253 \mathrm{~nm}$ was found to be high in control (with no CaTI) with respect to the proteinase activity in the presence of trypsin inhibitor in fusarium wilt resistant cultivar crude extract viz. JG 2001-12. The trypsin activity was calculated in units where, one unit of trypsin was defined as the amount that increased $\mathrm{A}_{428}$ by $0.01 / \mathrm{min}$ under the assay conditions.
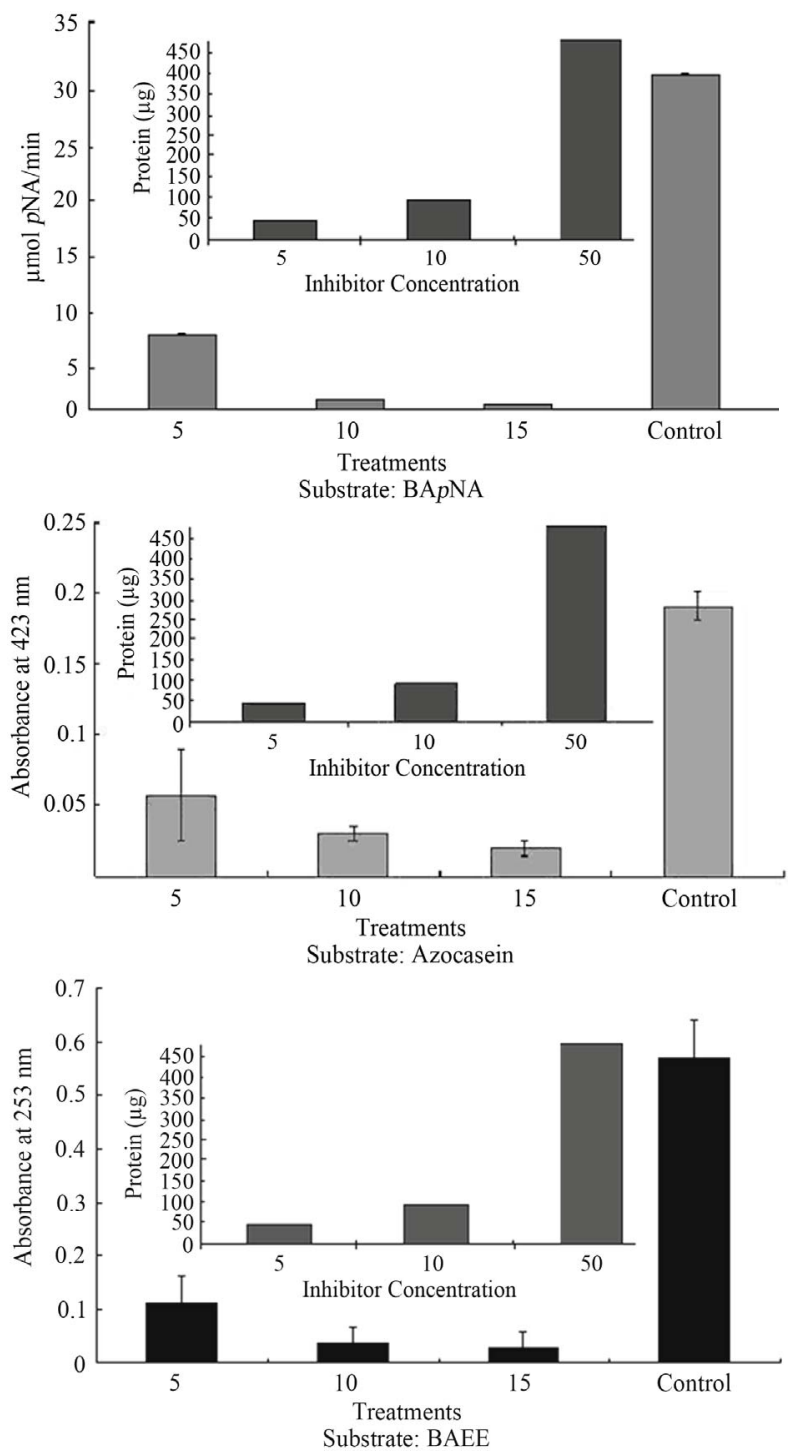

Figure 5. Effect of different concentration of trypsin inhibitor on activity of trypsin using synthetic substrates (BApNA, Azocasein, BAEE) as described in Materials and Methods. Error bars represent standard deviations. Inset, showing the protein concentration at different volume of trypsin inhibitor.

Trypsin inhibitory units were calculated from the number of trypsin units under similar conditions in the presence of trypsin inhibitor. $50 \mu \mathrm{l}$ of inhibitor $(320 \mu \mathrm{g}$ equivalent protein) was used as the optimum concentration so to inhibit trypsin activity. It was found that after $30 \mathrm{~min}$ of incubation, there was no increase in the absorbance at $428 \mathrm{~nm}$ and $253 \mathrm{~nm}$, suggesting an inhibition in trypsin activity (Figure 5). Our results demonstrated no variation in proteolytic activity of trypsin on natural and synthetic substrates in presence and absence of trypsin inhibitor. The results indicated that the crude extract of fusarium wilt resistant cultivar (viz. JG 2001-12) inhibit proteolysis of natural and synthetic substrates in the presence of bovine trypsin. The method we adopted here 
does not require ampholytes, so it is a cheaper and more convenient method. In the present study, a comparison on the trypsin inhibitor activity was carried out using different natural and synthetic substrates where, the TIA results were in conformity to Spelbrink et al. [16]. Earlier reports also suggest the use of both natural and synthetic substrates in determination of antitryptic activity as natural substrates are more difficult to displace from the active site to form the enzyme inhibitor complex while synthetic substrate are accurate in determining the inhibitor content of the materials [17] thereby providing a value with physiological relevance [16].

\subsection{Effect of Crude Extract of Seeds on the Mycelial Growth of Fusarium oxysporum f.sp. ciceris}

Studies have shown that an increasing level of proteinase inhibitor correlates to an increase in resistance against pathogens [18]. In many plant species, response to infection by pathogenic bacteria, viruses and fungi or to various abiotic stresses is accompanied by the synthesis of a variety of proteins termed as Pathogenesis related (PR) proteins [19], which have been isolated from both dicots and monocots [20]. Preliminary short report by Niderman et al. [20] has described a direct fungicidal activity of PR-1 protein from tomato. Similar results with PR-2, protein P14 against fungal pathogens have also been elucidated. In the present communication, crude extract of $C$. arietinum (L.) seed was preliminarily screened so to observe the effect of trypsin inhibitor on mycelial growth of Foc. The amount of proteins in the crude extract was equivalent to $3.5 \%$ in relation to the fresh weight of the seeds. The categorization of crude extracts as per TIA assay was also in accordance to the pathogenicity assay. Test plates containing crude extract of JG 2001-12, exhibited a colony diameter of $4.3 \pm 0.04$ $\mathrm{cm}$ whereas control plates exhibited a colony diameter of $9.0 \pm 0.05 \mathrm{~cm}$ (Figure 6(b)). Mycelial growth was found to be static with a decrease in colony diameter in presence of JG 2001-12 crude extract whereas susceptible cultivar, JG-16, and control plates where no crude extract was added showed no inhibition. Observations suggest CaTI to be antifungal, as JG 2000-12 showed significant antifungal activity w.r.t JG 16 cultivar, whose growth was analogous to control plates.

\subsection{Effect of gel filtration fractions (showing trypsin inhibitory activity) on the mycelial growth of $F$. oxysporum f.sp. ciceris}

Results showed a decrease in the growth of mycelia as the fraction showing trypsin inhibitor challenged the growth of Foc isolate \# $2087(3.0 \pm 0.04 \mathrm{~cm})$ as com-

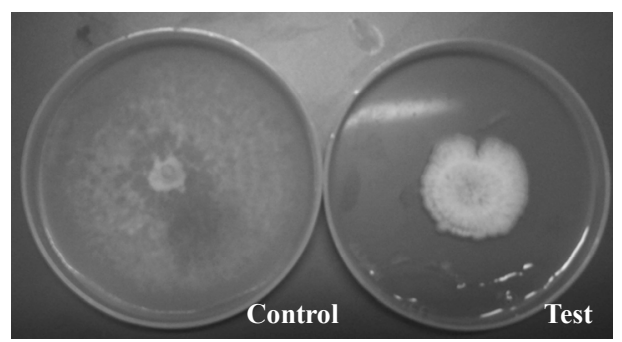

(a)

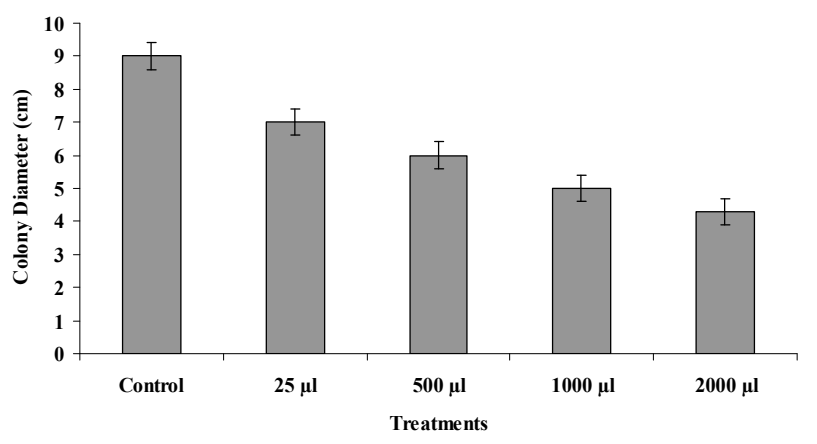

(b)

Figure 6. Effect of crude extract on the growth of Fusarium oxysporum f.sp. ciceris. (a) In vitro plate assay of crude extract from JG 2001-12 (T) on growth of Foc with respect to the control (C). (b) Effect of crude extract from JG 2001-12 on the growth of Foc

pared to the control where the growth of the isolate was found to be normal $(9.0 \pm 0.04 \mathrm{~cm})$. Gel filtrate fractions (fraction " $A$ ") showed a significant inhibition in fungal growth, indicating presence of trypsin inhibitor which led to inhibition in radial growth at protein concentration of $200 \mu \mathrm{g}$ (Table 3). Thus, demonstrating trypsin inhibitor's defensive role in inhibiting fungal growth. Using gel filtrate fraction, a 100-fold increase in inhibitory activity was observed over the crude inhibitor preparation against Foc (Table 3).

\subsection{Effect of Anion Exchange Fractions (Showing Trypsin Inhibitory Activity) on the Conidial Growth and Hyphal Length of $F$. oxysporum f.sp. ciceris}

As the volume of fractions achieved after anion exchange was small therefore, the purified trypsin inhibitor effect on conidial growth and hyphal length of Foc was observed. For most isolates, conidium germination decreased dramatically with increasing trypsin inhibitor (CaTI) concentration. Conidium germination was reduced to $50 \%$ at a CaTI concentration of $20 \mu \mathrm{g} \cdot \mathrm{mL}^{-1}$. After $12 \mathrm{~h}$ of incubation, a significant difference was observed both visually (Figure 7) and quantitatively (Figure 8) in fungal growth; as condium germination was found to be less as compared to the control (10\% PDB un-amended with CaTI). In 10\% PDB amended with 
Table 3. Effect of gel filtrate fraction "A" on growth of Fusarium oxysporum f. sp. ciceris at different concentration of protein $(\mu \mathrm{g})$.

\begin{tabular}{lcc}
\hline & Treatment & Colony diameter $(\mathbf{c m})$ \\
\hline 1$)$ & Control & $9.0 \pm 0.04$ \\
$2)$ & $10 \mu \mathrm{g}$ & $5.0 \pm 0.2$ \\
$3)$ & $100 \mu \mathrm{g}$ & $4.0 \pm 0.25$ \\
$4)$ & $200 \mu \mathrm{g}$ & $3.0 \pm 0.04$ \\
\hline
\end{tabular}
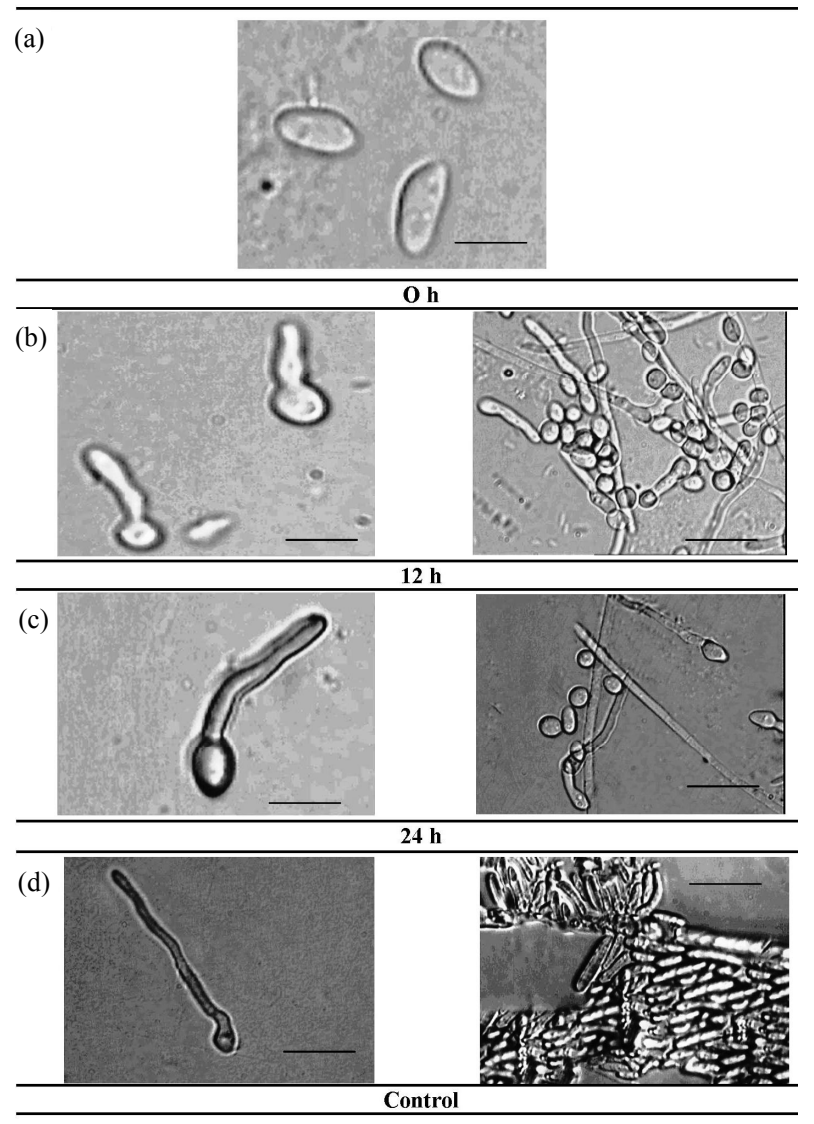

Figure 7. Inhibition of Fusarium oxysporum f.sp. ciceris conidia germination. Ion exchange chromatography fractions are mixed with PDB and incubated at $37^{\circ} \mathrm{C}$. Bar $=10 \mu \mathrm{m}$. (a) $10 \%$ potato dextrose broth (PDB) alone at $0 \mathrm{~h}$; (b) PDB amended with trypsin inhibitor $\left(20 \mu \mathrm{g} \cdot \mathrm{mL}^{-1}\right)$ at $12 \mathrm{~h}$; (c) PDB amended with trypsin inhibitor $\left(20 \mu \mathrm{g} \cdot \mathrm{mL}^{-1}\right)$ after $24 \mathrm{~h}$; (d) Control, with no trypsin inhibitor.

CaTI $\left(15 \mu \mathrm{g} \cdot \mathrm{mL}^{-1}\right)$, hyphal growth was observed to be $25 \mu \mathrm{m}$ as compared with $200 \mu \mathrm{m}$ in $10 \%$ PDB (control). At the end of $24 \mathrm{~h}$ of incubation, PDB amended with CaTI $\left(15 \mu \mathrm{g} \cdot \mathrm{mL}^{-1}\right)$ showed an increase in hyphal growth from $25 \mu \mathrm{m}$ to $52 \mu \mathrm{m}$, whereas there was a drastic increase in germination and hyphal growth of the mycelia $(340 \mu \mathrm{m})$ in $10 \%$ PDB (control).

At the end of $24 \mathrm{~h}$ of incubation, the hyphal length in the PDB amended with CaTI at $20 \mu \mathrm{g} \cdot \mathrm{mL}^{-1}$ remained

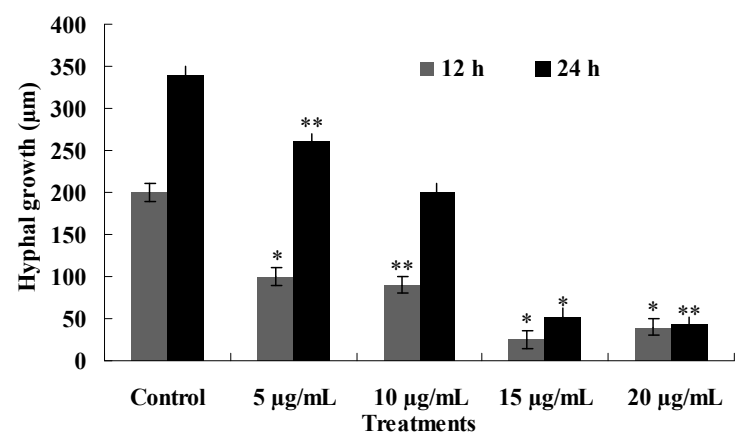

Figure 8. Fungal hyphal growth $(\mu \mathrm{m})$ with different treatments of trypsin inhibitor fractions of anion exchange column chromatography as described in Materials and Method.

nearly the same as that at $12 \mathrm{~h}$ with little variation (i.e. at $12 \mathrm{~h}$ the hyphal growth was found to be $40 \mu \mathrm{m}$ and after $24 \mathrm{~h}$ the hyphal growth was $42 \mu \mathrm{m}$ ). The results obtained using conidial germination and hyphal growth was in correlation to each other as the results showed inhibition in the presence of trypsin inhibitor were consistent (Figures 7 and 8). These studies were similar to Chen et al. [21] reports, which showed that the resistance of certain corn genotypes to fungal infection is related to the action of trypsin inhibitor, which is due to the lowering in the production and activity of fungal alpha-amylase, which in turn reduce the availability of simple sugars for fungal growth. Similar studies on the inhibition of spore germination and mycelium growth of Alternaria alternata by buckwheat trypsin/chymotrypsin was observed [22]. Likewise, cysteine proteinase inhibitors from pearl millet also inhibited the growth of many pathogenic fungi including Trichoderma reesei [23]. In addition, the antifungal effect of trypsin inhibitor was observed in wheat kernel [24], corn [21], barley [25] and cabbage [26].

Our results were in corroborance with Chen et al. [21], Huang et al. [27], Revina et al. [28] who described the use of resistant TI in inhibiting germination and hyphal growth of plant pathogenic fungi. Collating the present and previously reported data, it appears that Cicer arietinum trypsin inhibitor (CaTI) act as an antifungal agent since in vitro activity of CaTI showed a $45 \%-82 \%$ suppression of conidial germination and hyphal growth, thereby showing its effectiveness against Foc.

As Foc survives in soil, therefore use of TI containing Cicer arietinum L. (CaTI) would be an easy approach in order to reduce the use of chemicals/fungicides to combat Fusarium wilt. In the present study, a sustainable approach in controlling Fusarium wilt was utilized via the use of trypsin inhibitor as implementation of cultural, physical, biological and chemical measures minimize economic risks to consumers and the environment. To sum up, CaTI provide a defensive property to host plant 
as a cultivar containing trypsin inhibitor showed resistance against Fusarium wilt. In this context, future research to identify eco-friendly tools for the biological control of pathogens and further studies are warranted to confirm its biotechnological potential against other pathogens inflicting Cicer arietinum (L.).

\subsection{Abbreviations and Acronyms}

BAEE, N-benzoyl-L-Arg ethyl ester; BApNA, N- $\alpha$ Benzoyl-D, L-arginine $p$-nitroanilide hydrochloride; CLA, carnation leaf agar; CaTI, Cicer arietinum Trypsin Inhibitor; Foc, Fusarium oxysporum f.sp. ciceris; PDA, Potato Dextrose Agar; PDB, Potato Dextrose Broth; p-NA, para-nitroaniline; TI, Trypsin Inhibitor; TIA, Trypsin Inhibitor Activity; TCA, Trichloroacetic acid.

\section{ACKNOWLEDGEMENTS}

The authors would like to thank the Head of the Department of Biological Sciences, Rani Durgavati University, Jabalpur (India) for laboratory facilities and University Grant Commission Project (Govt. of India), New Delhi for financial assistance vide project no. UGC (32-370/2006) (SR) dated. 24/04/07. Authors also acknowledge JNKVV, Jabalpur, India for providing the seed material.

\section{REFERENCES}

[1] Varshney, R.K., Song, C., Saxena, R.K., Azam, S., Yu, S., Sharpe, A.G. Cannon, S., Baek, J., Rosen, B.D., Tar'an, B., Millan, T., Zhang, X., Ramsay, L.D., Iwata, A., Wang, Y., Nelson, W., Farmer, A.D., Gaur, P.M., Soderlund, C., Penmetsa, R.V., Xu, C., Bharti, A.K., He, W., Winter, P., Zhao, S., Hane, J.K.,Carrasquilla-Garcia, N., Condie, J.A., Upadhyaya, H.D., Luo, M.C., Thudi, M., Gowda, C.L., Singh, N.P., Lichtenzveig, J., Gali, K.K., Rubio, J., Nadarajan, N., Dolezel, J., Bansal, K.C., Xu, X., Edwards, D., Zhang, G., Kahl, G., Gil, J., Singh, K.B., Datta, S.K., Jackson, S.A., Wang, J. and Cook, D.R. (2013) Draft genome sequence of chickpea (Cicer arietinum) provides a resource for trait improvement. Nature Biotechnology, 31, 240-246. http://dx.doi.org/10.1038/nbt.2491

[2] Landa, B.B., Navas-Cortés, J.A., Jiménez-Gasco, M.M., Katan, J., Retig, B. and Jiménez-Díaz, R.M. (2006) Temperature response of chickpea cultivars to races of $\mathrm{Fusa}$ rium oxysporum f. sp. ciceris, causal agent of Fusarium wilt. Plant Disease, 90, 365-374.

http://dx.doi.org/10.1094/PD-90-0365

[3] Haware, M.P., Nene, Y.L. and Natarajan, M. (1996) The survival of Fusarium oxysporum f. sp. ciceri in the soil in the absence of chickpea. Phytopathologia Mediterranea, 35, 9-12.

[4] Sharma, K.D. and Muehlbauer, F.J. (2007) Fusarium wilt of chickpea: Physiological specialization, genetics of resistance and resistance gene tagging. Euphytica, 157, 1-14. http://dx.doi.org/10.1007/s10681-007-9401-y

[5] Habib, H. and Fazili, K.M. (2007) Plant protease inhibitors: A defense strategy in plants. Biotechnology and Mo- lecular Biology Review, 2, 68-85.

[6] Zavala, J.A., Patankar, A.G., Gase, K., Hui, D. and Baldwin, I.T. (2004) Manipulation of endogenous trypsin proteinase inhibitor production in Nicotiana attenuata demonstrates their function as antiherbivore defenses. Plant Physiology, 134, 1181-1190.

http://dx.doi.org/10.1104/pp.103.035634

[7] Srinivasan, A., Chougule, N.P., Giri, A.P., Gatehouse, J.A. and Gupta, V.S. (2005) Podborer (Helicoverpa armigera Hübn.) does not show specific adaptations in gut proteinases to dietary Cicer arietinum Kunitz proteinase inhibitor. Journal of Insect Physiology, 51, 1268-1276. http://dx.doi.org/10.1016/j.jinsphys.2005.07.005

[8] Nair, M., Singh, S.S. and Babbar, A. (2013) Purification of trypsin inhibitor (TI) from seeds of Cicer arietinum (L.) and its insecticidal potentiality against Helicoverpa armigera (Hübner). Theoretical and Experimental Plant Physiology, Vol. 25, No. 2, pp. 141-152.

[9] Brock, F.M., Forsberg, C.W. and Buchanan-Smith, J.G. (1982) Proteolytic activity of rumen microorganisms and effects of proteinase inhibitors. Applied and Environmental Microbiology, 44, 561-569.

[10] Lowry, O., Rosbrough, N., Farr, A. and Randall, R. (1951) Protein measurement with the folin phenol reagent. Journal of Biological Chemistry, 193, 265-275.

[11] Laemmli, U.K. (1970) Cleavage of structural proteins during the assembly of head of bacteriophage T4. Nature, 227, 680-685. http://dx.doi.org/10.1038/227680a0

[12] Le, Q.T. and Katunuma, N. (2004) Determination of protease inhibitors by a reverse zymography method performed in a Tris-Tricine buffer system. Analytical Biochemistry, 324, 237-240. http://dx.doi.org/10.1016/j.ab.2003.09.033

[13] Schwert, W.H. and Takenaka, Y. (1955) A spectrophotometric determination of trypsin and chymotrypsin. Biochimica Biophysica Acta, 16, 570-575. http://dx.doi.org/10.1016/0006-3002(55)90280-8

[14] Gatehouse, A.M.R., Gatehouse, J.A. and Boulter, D. (1980) Isolation and characterization of trypsin inhibitors from cowpea (Vigna unguiculata). Phytochemistry, 19, $751-756$ http://dx.doi.org/10.1016/0031-9422(80)85104-1

[15] Tremacoldi, C.R. and Pascholati, S.F. (2002) Detection of trypsin inhibitor in seeds of Eucalyptus urophylla and its influence on the in vitro growth of the fungi Pisolithus tinctorius and Rhizoctonia solani. Brazilian Journal of Microbiology, 33, 281-286. http://dx.doi.org/10.1590/S1517-83822002000400001

[16] Spelbrink, R.E.J., Gerrits, P.J., Mooij, C. and Giuseppin, M.L.F. (2011) Quantitative Determination of Trypsin Inhibitory Activity in Complex Matrices. Open Food Science Journal, 5, 42-46. http://dx.doi.org/10.2174/1874256401105010042

[17] Kakade, M.L., Simons, N. and Liener, I.E. (1969) An evaluation of natural vs. synthetic substrates for measureing the antitryptic activity of soybean samples. Cereal Chemistry, 46, 518-526.

[18] Woloshuk, C.P., Meulenhoff, J.S., Sela-Buurlage, M., van den Elzen, P.J.M. and Cornelissen, B.J.C. (1991) Patho- 
gen-induced proteins with inhibitory activity toward Phytophthora infestans. Plant Cell, 3, 619-628. http://dx.doi.org/10.1105/tpc.3.6.619

[19] Stintzi, A., Heitz, T., Prasad, V., Wiedemann-Merdinoglu, S., Kauffmann, S., Geoffroy, P., Legrand, M. and Fritig, B. (1993) Plant "Pathogenesis-related" proteins and their role in defense against pathogens. Biochimie, 75, 687706. http://dx.doi.org/10.1016/0300-9084(93)90100-7

[20] Niderman, T., Genetet, I., Bruyère, T., Gees, R., Stintzi, A., Legrand, M., Fritig, B. and Mösinger, E. (1995) Pathogenesis-related PR-1 proteins are antifungal. Plant Physiology, 108, 17-27. http://dx.doi.org/10.1104/pp.108.1.17

[21] Chen, Z-Y., Brown, R.L., Russin, J.S., Lax, A.R. and Cleveland, T.E. (1999) A corn trypsin inhibitor with antifungal activity inhibits Aspergillus flavus a-amylase. Phytopathology, 89, 902-907. http://dx.doi.org/10.1094/PHYTO.1999.89.10.902

[22] Dunaevskii, Y.E., Gladysheva, I.P., Pavlukova, E.B., Beliakova, G.A., Gladyschev, D.P., Papisova, A.I., Larionova, N.I. and Belozersky, M.A. (1997) The anionic protease inhibitor BBWI-1 from buckwheat seeds. Kinetic properties and possible biological role. Physiologia Plantarum, 100, 483-488. http://dx.doi.org/10.1111/j.1399-3054.1997.tb01027.x

[23] Joshi, B., Sainani, M., Bastawade, K., Gupta, V.S. and Ranjekar, P.K. (1998) Cysteine protease inhibitor from pearl millet: A new class of antifungal protein. Biochemical and Biophysical Research Communications, 246, 382-
387. http://dx.doi.org/10.1006/bbrc.1998.8625

[24] Chilosi, G., Caruso, C., Caporale, C., Leonardi, L., Bertini, L., Buzi, A., Nobile, M., Magro, P. and Buonocore, V. (2000) Antifungal activity of a Bowman-Birk-type trypsin inhibitor from wheat kernel. Journal of Phytopathology, 148, 477-481.

http://dx.doi.org/10.1046/j.1439-0434.2000.00527.x.

[25] Terras, F.R.G., Schoofs, H.M.E., Thevissen, K., Osborn, R.W., Vanderleyden, J., Cammue, B.P.A. and Broekaert, W.F. (1993) Synergistic enhancement of the antifungal activity of wheat and barley thionins by radish and oilseed rape $2 \mathrm{~S}$ albumins and by barley trypsin inhibitors. Plant Physiology (Rockville), 103, 1311-1319.

[26] Lorito, M., Broadway, R.M., Hayes, C.K., Woo, S.L., Noviello, C., Williams, D.L. and Harman, G.E. (1994) Proteinase inhibitors from plants as a novel class of fungicides. Molecular Plant-Microbe Interactions, 7, 525527. http://dx.doi.org/10.1094/MPMI-7-0525

[27] Huang, H., Qi, S.D., Qi, F., Wu, C.A., Yang, G.D. and Zheng, C.C. (2010) NtKTI1, a Kunitz trypsin inhibitor with antifungal activity from Nicotiana tabacum, plays an important role in tobacco's defense response. FEBS Journal, 277, 4076-4088. http://dx.doi.org/10.1111/j.1742-4658.2010.07803.x

[28] Revina, T.A., Parfenov, I.A., Gvozdeva, E.L., Gerasimova, N.G. and Valueva, T.A. (2011) Chymotrypsin and trypsin inhibitor isolated from potato tubers. Prikladnaya Biokhimiya i Microbiologiya, 47, 265-271. 